\title{
An experimental model for ascending acute pyelonephritis caused by Escherichia coli or proteus in rats
}

\author{
P LARSSON* $\dagger$, B KAIJSER* $\uparrow$, I MATTSBY BALTZER $\dagger$, AND S OLLING $\ddagger$ \\ From the Departments of *Clinical Bacteriology and †Clinical Immunology, Institute of Medical \\ Microbiology and $\ddagger$ Department of Pathology, University of Göteborg, Göteborg, Sweden
}

SUMMARY Experimental, ascending acute pyelonephritis in rats was produced by injecting $0.5 \mathrm{ml}$ of $10^{9} \mathrm{bacteria} / \mathrm{ml}$ into the urinary bladder via the urethra. No traumatic manipulation of the ureters of kidneys was necessary. A grading system for kidney lesions based on macro- and microscopical examination was used.

The capacity of different Escherichia coli and proteus strains to induce acute pyelonephritis was tested, and the $E$. coli $06 \mathrm{~K} 13 \mathrm{H} 1$ strain and the Proteus mirabilis $03 \mathrm{H} 1$ strain were especially capable of causing urinary tract infection. For the $P$. mirabilis $03 \mathrm{H} 1$ strain, a dominance of right kidney lesions was noted in contrast to the $E$. coli $06 \mathrm{~K} 13 \mathrm{H} 1$ strain which did not show any side preference.

Experimental in vivo models are necessary for studies of urinary tract infection (UTI). Several procedures have been developed to study the pathophysiology of kidney damage, the effect of antibiotic treatment, prophylactic immunisation, and other aspects on the host-parasite relationship in UTI. ${ }^{1-10}$

Several animal species used do not readily develop UTI, and most experimental models therefore include mechanical manipulations of the urinary tract to ensure a high frequency of pyelonephritic infections. Examples of such manipulations are bladder or kidney massage, 141112 abdominal operations, often with temporary ureteral ligation or puncture of the kidneys or bladder wall, $5713-16$ and introduction of foreign bodies into the bladder. ${ }^{12}$ 17-19 Forced diuresis by the addition of glucose to the drinking water also facilitates the development of pyelonephritis. ${ }^{613}$ Hormone treatment for induction of pyelonephritis has given contradictory results. 2021

Urinary tract infection in man is considered to be of ascending origin, except in the very young and very old. The experimental methods mentioned above hardly resemble the development of ascending UTI in man. Pyelonephritis after introduction of bacteria via the urethra into the bladder without additional manipulations would be preferable. As

Received for publication 25 October 1979 rats have spontaneous ureteric reflux, allowing for easy passage of bacteria up to the renal pelvis, such animals seem to be suitable for experimental ascending pyelonephritis. ${ }^{118}$ Several reports have dealt with methods for establishing retrograde UTI in rats but have mostly included manipulations of the urinary tracts. ${ }^{2} 51216171922$

The aim of the present investigation was to develop and evaluate a model for ascending acute pyelonephritis in rats, without special manipulations of the urinary tract, suitable for studies on the immune response, and the protective effect of vaccination against UTI.

\section{Material and methods}

ANIMALS

Female Sprague-Dawley rats weighing 200 to $300 \mathrm{~g}$ (Anticimex, Stockholm, Sweden) were used. They were fed with pellets and tap water ad libitum.

BACTERIAL STRAINS

The following Escherichia coli standard strains from the Collaborative Centre for Reference and Research on Escherichia (WHO), Statens Serum Institut, Copenhagen, Denmark, were used (WHO designation in parentheses): 01K1H7 (U5/41), 02K1H4 (U9/41), 04K12H- (Su65/42), 06K13H1 (Su4344/ 41), 07K1H- (Bi7509/41). Most experiments were performed with the $E$. coli $06 \mathrm{~K} 13 \mathrm{H} 1$ strain, as it had 
previously been found regularly to cause pyelonephritis in animal models. ${ }^{7} 8$ The following Proteus mirabilis and vulgaris strains were used (Kauffmann and Perch designation ${ }^{23}$ in parentheses): $01 \mathrm{H} 1$ (XL), 03H1 (XK), 010H3 (F73). The bacterial strains were cultivated in nutrient broth at $37^{\circ} \mathrm{C}$ overnight. The bacteria were washed once with saline and then adjusted to the desired concentration. In early experiments the bacterial dose was determined by viable counts on agar plates and optical density, and later with optical density alone.

\section{INFECTION PROCEDURES}

\section{Ascending pyelonephritis}

The bacteria were introduced via the urethra into the urinary bladder of ether anaesthetised rats using a blunt, slightly bent needle. Different volumes $(0 \cdot 1$ $2.0 \mathrm{ml})$ and concentrations of bacteria $\left(10^{7}-10^{10}\right.$ bacteria/ml) were tested for infection but the standard dose was $0.5 \mathrm{ml}$ of $10^{9}$ bacteria $/ \mathrm{ml}$ in phosphate buffered saline (PBS). The bacteria were injected into the bladder for about a 5-second period.

Blood samples were obtained from 50 rats 15-30 minutes after bacterial injection of $0 \cdot 25-2 \cdot 0 \mathrm{ml}$ and cultivated in standard blood culture bottles containing solid and liquid media.

After one week of infection the animals were killed and the kidneys removed under sterile conditions. Cut kidney surfaces were inoculated on modified Drigalski ${ }^{23}$ and/or CLED agar plates (Oxoid) for confirmation of the infecting strain. Serotypings of $E$. coli $\mathrm{O}$ antigen, ${ }^{24} \mathrm{~K}$ antigen, ${ }^{25}$ and proteus $\mathrm{O}$ antigen ${ }^{26}$ were performed as earlier described.

Microscopical examination was performed blindly on formalin-fixed $(10 \%)$ kidney specimens.

\section{Grading of kidney lesions}

Kidney lesions were graded, based on gross examination and light microscopy using a classification modified from MacLaren:27

$0=$ unaffected kidney

$1=$ microscopical pyelitis

$2=$ microscopical pyelonephritis with no or one to two discrete macroscopical pinpoint abscesses

3 = several macroscopical pinpoint abscesses showing coalescence

$4=$ confluent macroscopical lesions occupying less than half of the kidney surface

$5=$ confluent macroscopical lesions occupying more than half of the kidney surface.

\section{Control experiments}

(1) Increased pressure in the renal pelvis caused by the injected volume has been considered to cause endothelial damage which might facilitate the development of a local pyelonephritis due to bacteria originating from the urinary tracts or the bloodstream. ${ }^{42}$ This was tested by injecting sterile PBS $(0,0.25$, or $0.5 \mathrm{ml})$ into the urinary bladder of 60 rats. Immediately afterwards an intracardiac injection of $E$. coli $\left(10^{3}\right.$ or $10^{5}$ bacteria in $\left.0.5 \mathrm{ml}\right)$ was given. This procedure did not cause haematogenous pyelonephritis. However, 12 animals died within two days, presumably of bacteraemia.

(2) The following control experiment was performed in order to analyse whether serum antibodies can leak into the urine via damaged kidneys and thus interfere with studies on local immunity. Rat anti-E. coli 02 serum was injected intravenously into 10 rats, in whom ascending $E$. coli $06 \mathrm{~K} 13 \mathrm{H} 1$ pyelonephritis had been induced one week previously. In four of these rats, who were later found to have severe acute pyelonephritis (grades 4-5), serum and urine samples were analysed for anti-E. coli 02 antibodies. In urine samples obtained one day and one week after the serum transfer, no 02 antibodies of the IgG, IgA, or IgM classes could be detected with the enzyme-linked immunosorbent assay using boiled 02 antigen for coating of the tubes. ${ }^{28} \mathrm{~A}$ significant rise in serum antibodies could be recorded, however.

Statistical calculations were made using the $\chi^{2}$ test and the Kolmogorov-Smirnov test. ${ }^{29}$

\section{Result}

PYELONEPHRITIS CAUSED BY E. coli $06 \mathrm{~K} 13 \mathrm{H} 1$ Intravesical introduction of large volumes (0.6$2.0 \mathrm{ml}$ ) caused bacteraemia with the $06 \mathrm{~K} 13 \mathrm{H} 1$ strain (Table 1), as determined with blood cultures 15-30 minutes after the bacterial injection. As $0.5 \mathrm{ml}$ caused no bacteraemia, this was used as the standard volume in subsequent ascending pyelonephritis experiments. The standard procedure with $0.5 \mathrm{ml}$ of $10^{9}$ bacteria $/ \mathrm{ml}$ gave rise to acute pyelonephritis in about $60 \%$ (grades $2-5$, value of worst damaged

Table 1 Bacteraemia in rats as determined with blood cultures obtained 15-30 minutes after intravesical injection of $\mathrm{E}$. coli $06 \mathrm{~K} 13 \mathrm{HI}$ $\left(10^{\circ}\right.$ bacteria $\left./ \mathrm{ml}\right)$

\begin{tabular}{lll}
\hline Volume injected $(\mathrm{ml})$ & Total no. of animals & $\begin{array}{l}\text { No. of animals with } \\
\text { positive blood culture }\end{array}$ \\
\hline 2.0 & 7 & 7 \\
1.0 & 8 & 8 \\
0.75 & 9 & 4 \\
0.6 & 6 & 1 \\
0.5 & 10 & 0 \\
0.25 & 10 & 0 \\
\hline
\end{tabular}


Table 2 Frequency, grading, and side of renal lesions in rats intravesically infected with $\mathrm{E}$. coli $06 \mathrm{~K} 13 \mathrm{HI}$ or P. mirabilis $03 H 1$. Grading system as in Material and methods

\begin{tabular}{|c|c|c|c|c|c|c|c|c|c|c|c|c|}
\hline \multirow[t]{2}{*}{ Bacteria injected } & \multirow{2}{*}{$\begin{array}{l}\text { No. of rats with } \\
\text { kidney lesions* }\end{array}$} & \multicolumn{3}{|c|}{ No. of rats with pyelonephritis localised to: } & \multirow{2}{*}{$\begin{array}{l}\text { No. of rats } \\
\text { with pyelitis }\end{array}$} & \multicolumn{7}{|c|}{ Grading of kidney lesions } \\
\hline & & Right kidney & Left kidney & Both kidneys & & & 0 & 1 & 2 & 3 & 4 & 5 \\
\hline \multirow[t]{2}{*}{ E. coli $06 \mathrm{~K} 13 \mathrm{H} 1$} & 113 & 16 & 19 & 47 & 31 & Right & $9 \dagger$ & 40 & 16 & 18 & 13 & 17 \\
\hline & & & & & & Left & 23 & 23 & 19 & 10 & 22 & 16 \\
\hline \multirow[t]{2}{*}{ P. mirabilis $03 \mathrm{H} 1$} & 135 & 63 & 12 & 59 & 1 & Right & 8 & 5 & 23 & 26 & 36 & 37 \\
\hline & & & & & & Left & 56 & 8 & 13 & 22 & 19 & 17 \\
\hline
\end{tabular}

${ }^{*}$ Grades 1-5. †No. of kidneys.

kidney). The distribution of renal lesions is shown in Table 2. Reduction of the bacterial dose to $10^{7}$ bacteria/ml in $0.5 \mathrm{ml}$ gave a pyelonephritis rate of only $11 \%$. In control experiments, the same number of bacteria as in the standard procedure, but given in a smaller volume $(0 \cdot 1 \mathrm{ml})$, caused no pyelonephritis.

PYELONEPHRITIS CAUSED BY OTHER

BACTERIAL STRAINS

Injection of the other $E$. coli strains using the standard procedure $\left(0.5 \mathrm{ml} ; 10^{9}\right.$ bacteria/ml $)$ gave attack rates less than $40 \%$. Infection with the $P$. mirabilis $03 \mathrm{H} 1$ strain, standard procedure, gave an attack rate similar to that of $E$. coli $06 \mathrm{~K} 13 \mathrm{H} 1$ (70$80 \%$ ). The other proteus strains gave lower frequencies of pyelonephritis $(<50 \%)$.

PYELONEPHRITIS IN LEFT AND/OR RIGHT KIDNEY

Analysis of ascending pyelonephritis in rats infected with $E$. coli $06 \mathrm{~K} 13 \mathrm{H} 1$ or $P$. mirabilis $03 \mathrm{H} 1$ revealed a significant difference concerning the distribution of kidney lesions (Table 2). Pyelonephritis caused by $P$. mirabilis $03 \mathrm{H} 1$ developed significantly more often in the right kidney than in the left $\left(\mathrm{P}<0.001, \chi^{2}\right.$ test and Kolmogorov-Smirnov test). Kidney lesions caused by the $E$. coli $06 \mathrm{~K} 13 \mathrm{H} 1$ strain showed no side preference.

\section{Discussion}

The importance of the volume injected into the urinary bladder to cause ascending pyelonephritis has been much discussed. ${ }^{2} 416182230$ The ideal is to use volumes large enough to give reflux without damaging the renal epithelium and causing bacteraemia and haematogenous pyelonephritis. ${ }^{16}$ In the present study, intravesical injection of large volumes $(0 \cdot 6-2 \cdot 0 \mathrm{ml})$ of $E$. coli $06 \mathrm{~K} 13 \mathrm{H} 1$ caused bacteraemia. Similar findings were reported earlier. ${ }^{42}$ Even a volume of $0.5 \mathrm{ml}$ has been shown to give positive blood cultures. ${ }^{422}$ In the latter study, this was found in rats deprived of drinking water. In the former, several bladder squeezes were performed immediately after the bacterial injection.

In adult rats with free access to drinking water, reflux regularly occurs at $0 \cdot 5-0 \cdot 6 \mathrm{ml}$, although it has also been shown to occur at lower volumes. ${ }^{1822} 30$ In rats deprived of water, reflux occurs regularly at lower volumes $(0 \cdot 25 \mathrm{ml}) .^{22}$

In the present investigation, the optimal volume for developing pyelonephritis was $0.5 \mathrm{ml}$, with which about $60 \%$ of the animals contracted disease. Similar attack rates were reported by Vivaldi et al. ${ }^{1-}$ Andersen and Jackson, ${ }^{30}$ and Fierer et al. ${ }^{22}$ In the two first studies, however, manipulations or larger volumes were used.

The work by Morgan et al. ${ }^{31}$ showed that intravesical injection of sterile saline caused a decrease in the ability of rats to clear the kidneys of bacteria injected intravenously. These experiments were terminated after 24 hours, and the frequency of pyelonephritis was not determined. In the present investigation, intravesical injection of up to $0.5 \mathrm{ml}$ of sterile PBS, followed by intracardiac injection of E. coli $06 \mathrm{~K} 13 \mathrm{H1}$, caused no pyelonephritis. This suggests that the volume of $0.5 \mathrm{ml}$ caused no severe epithelial damage. In the report by Fierer et al. 2.2 $1.0 \mathrm{ml}$ of sterile broth infused into the bladder, followed by $E$. coli injected intravenously, caused pyelonephritis.

The optimal number of bacteria injected to cause pyelonephritis was in this series determined as $10^{9}$ bacteria $/ \mathrm{ml}$ for the $E$. coli $06 \mathrm{~K} 13 \mathrm{H1}$ and the $P$. mirabilis $03 \mathrm{H} 1$ strains. Reports from experiments using other bacterial strains have shown differing doses and attack rates. ${ }^{2} 512162030$ This might be explained by the fact that bacterial strains with different virulence factors such as 0 and $\mathrm{K}$ antigens and serum resistance have been used, or that differences in susceptibility to bacteria exist among rat strains. Another explanation could be that, although a defined inoculum is injected, the rats often void shortly afterwards, making the exact infecting dose thus hard to define. 
As pointed out by Heptinstall, ${ }^{32}$ organisms residing in the rat urethra may be carried up to the kidney during injection and cause infection. To exclude this possibility, the identity of the infecting strain should be confirmed for the renal isolates. In the present work this was done with serological methods.

To compare renal damage in immunised and control groups of animals, a relevant grading system is important. Often only grading of pyelonephritis into damaged-non-damaged kidneys has been used. ${ }^{162230}$ Statistical calculations have also been performed on mean values of arbitrary units. ${ }^{527} \mathrm{~A}$ more elaborate grading system based on both macro- and microscopical kidney appearances was adopted in this study, using the non-parametric Kolmogorov-Smirnov test for the statistical calculations.

In this work a marked predominance of $P$. mirabilis $03 \mathrm{H} 1$ pyelonephritis in the right kidney was found, compared to $E$. coli $06 \mathrm{~K} 13 \mathrm{H} 1$ induced pyelonephritis. No obvious explanation for such side preferences could be found. In the work of Adler et $a l .12$ no such side differences were shown for $E$. coli and proteus. In most studies in which no manipulation of one of the kidneys or ureters has been done, separate values for right and left kidneys are not given. The possibility of different attack rates on right and left kidneys favours the use of the graded value of the worst damaged kidney for statistical calculations. ${ }^{10}$

In conclusion, the method presented for inducing ascending acute pyelonephritis in rats is reliable and simple and requires no special manipulations of the urinary tracts. An appropriate volume and number of bacteria should be injected and virulent bacteria should be used.

The skilful technical assistance of Ms Gunvor Jefferth, Ms Helena Kahu, Ms Kerstin Larsson, and Ms Kerstin Lundqvist is very much appreciated. We are also indebted to Ms Kerstin Bohman for excellent typing of the manuscript. The investigation was supported by grants from the Swedish Medical Research Council (project No. 215) and from STU, Sweden (project No. 78-3452).

\section{References}

${ }^{1}$ Sanford JP, Hunter BW, Souda LL. The role of immunity in the pathogenesis of experimental hematogenous pyelonephritis. J Exp Med 1962;115: 383-410.

${ }^{2}$ Cotran RS, Vivaldi E, Zangwill DP, Kass EH. Retrograde proteus pyelonephritis in rats. Bacteriologic, pathologic and fluorescent-antibody studies. $A m \vec{J}$ Pathol $1963 ; 43: 1-21$.
${ }^{3}$ Hunter BW, Souda LL, Sanford JP. Antibiotic therapy in established chronic experimental Proteus mirabilis pyelonephritis. Antimicrob Agents Chemother 1963; 3:608-12.

${ }^{4}$ Heptinstall RH. Experimental pyelonephritis. Bacteriological and morphological studies on the ascending route of infection in the rat. Nephron 1964;1:73-92.

${ }^{5}$ Hunter BW, Akins LL, Sanford JP. The role of immunity in the pathogenesis of experimental retrograde pyelonephritis. J Exp Med 1964;119:869-79.

${ }^{6}$ Hubert EG, Kalmanson GM, Guze LB. Antibiotic therapy of Escherichia coli pyelonephritis produced in mice undergoing chronic diuresis. Antimicrob Agents Chemother 1968;8:507-10.

${ }^{2}$ Kaijser B, Olling S. Experimental hematogenous pyelonephritis due to Escherichia coli in rabbits: the antibody response and its protective capacity. $J$ Infect Dis $1973 ; 128: 41-9$.

${ }^{8}$ Kaijser B, Larsson P, Olling S. Protection against ascending Escherichia coli pyelonephritis in rats and significance of local immunity. Infect Immun 1978; 20:78-81.

${ }^{9}$ Larsson P, Kaijser B, Olling S, Sohl Åkerlund A. Protection against experimental Proteus mirabilis pyelonephritis in rats and significance of immunity. Acta Pathol Microbiol Scand [C] 1978;86:215-20.

${ }^{10}$ Larsson P, Kaijser B, Mattsby Baltzer I, Olling S. Protective effect of immunization with Salmonella minnesota $\operatorname{Re} 595$ against ascending Escherichia coli 06K13H1 pyelonephritis in the rat. Scand $J$ Infect Dis 1980 , in press.

${ }^{11}$ Braude AI, Shapiro AP, Siemienski J. Hematogenous pyelonephritis in rats. III. Relationship of bacterial species to the pathogenesis of acute pyelonephritis. $J$ Bact 1959;77:270-80.

12 Adler CP, Ritzmann H, Zollinger HU. Vergleichende Untersuchungen über die hämatogene und die ascendierende Pyelonephritis bei Ratten. Virchows Arch [Pathol Anat] 1969;347:277-95.

${ }^{13}$ Freedman LR. Experimental pyelonephritis. XIII. On the ability of water diuresis to induce susceptibility to $E$. coli bacteriuria in the normal rat. Yale J Biol Med 1967;39:255-66.

14 Prát V, Losse H, Koničková L, Ritzerfeld W. Experimental ascending Eschericha coli pyelonephritis in the rat. Invest Urol 1970;8:311-18.

15 Miller TE, Robinson KB. Experimental pyelonephritis: a new method for inducing pyelonephritis in the rat. $J$ Infect Dis 1973;127:307-10.

${ }^{16}$ Brooks SJD, Lyons JM, Braude AI. Immunization against retrograde pyelonephritis. I. Production of an experimental model of severe ascending Escherichia coli pyelonephritis without bacteremia in rats. $\mathrm{Am}$ $J$ Pathol 1974;74:345-58.

17 Vivaldi E, Cotran R, Zangwill DP, Kass EH. Ascending infection as a mechanism in pathogenesis of experimental non-obstructive pyelonephritis. Proc Soc Exp Biol Med 1959;102:242-4.

${ }^{18}$ Sommer JL. Experimental pyelonephritis in the rat with observations on ureteral reflux. J Urol $1961 ; 86$ : 375-81.

${ }^{19}$ Musher DM, Griffith DP, Yawn D, Rossen RD. Role 
of urease in pyelonephritis resulting from urinary tract infection with proteus. J Infect Dis 1975;131: 177-81.

${ }^{20}$ Henkel W, Commichau R. Serumresistenz und 'Nephropathogenität' antigenetisch definierter Stämme von E. coli. III. Experimentelle Pyelonephritis mit unterschiedlich serum-resistenten Keimen. Z Med Mikrobiol Immunol 1971;156:297-304.

${ }^{21}$ Loew H, Bronder B, Ritzerfeld W. Untersuchungen über die hormonell gebahnte experimentelle Escherichia coli-Pyelonephritis der Ratte. Int J Clin Pharmacol Biopharm 1973;7:303-6.

${ }^{22}$ Fierer J, Talner L, Braude AI. Bacteremia in the pathogenesis of retrograde $E$. coli pyelonephritis in the rat. Am J Pathol 1971;64:443-56.

${ }^{23}$ Kauffmann F. The Bacteriology of Enterobacteriaceae. 2nd ed. Copenhagen: Munksgaard, 1969.

${ }^{24}$ Lidin-Janson G, Falsen E, Jodal U, Kaijser B, Lincoln K. Characteristics of antibiotic-resistant Escherichia coli in the rectum of healthy school-children. $J$ Med Microbiol 1977;10:299-308.

${ }^{25}$ Kaijser B. A simple method for typing of acidic polysaccharide $\mathrm{K}$ antigens of E. coli. FEMS Microbiol Lett 1977;1:285-8.

${ }^{26}$ Larsson P, Olling S. O antigen distribution and sensiti- vity to the bactericidal effect of normal human serum of proteus strains from clinical specimens. Med Microbiol Immunol 1977;163:77-82.

${ }^{27}$ MacLaren DM. The significance of urease in proteus pyelonephritis: a bacteriological study. J Pathol Bacteriol 1968;96:45-56.

${ }^{28}$ Engvall E, Perlmann P. Enzyme-linked immunosorbent assay, ELISA. III. Quantitation of specific antibodies by enzyme-labeled anti-immunoglobulin in artigen-coated tubes. J Immunol 1972;109:129-35.

${ }^{29}$ Siegel S. Nonparametric Statistics for the Behavioural Sciences. New York: McGraw-Hill, 1956:127-36.

${ }^{30}$ Andersen BR, Jackson GG. Pyelitis, an important factor in the pathogenesis of retrograde pyelonephritis. J Exp Med 1961;114:375-84.

${ }^{31}$ Morgan M, Asscher AW, Moffat DB. The role of vesico-ureteric (V-U) reflux in the pathogenesis of kidney scars in the rat. Nephron 1976;17:8-19.

${ }^{32}$ Heptinstall RH. Experimental pyelonephritis. Ascending infection of the rat kidney by organisms residing in the urethra. Br J Exp Pathol 1964;45:436-41.

Requests for reprints to: Dr P Larsson, Institute of Medical Microbiology, University of Göteborg, Guldhedsgatan 10, S-413 46 Göteborg, Sweden. 